Egyptian J. of Nutrition Vol. XXXIII No. 3 (2018)

\title{
Nutritional And Biochemical Effects Of Gum Arabic On The Pathological Changes Reduction Of Alloxan Induced Diabetic Rats
}

\author{
Ensaf M. Yassin \\ Nutrition and Food Science Dept, Faculty of Home Economics, Al- \\ Azhar University, Egypt
}

\begin{abstract}
Natural substances have been used as a source of medicinal treatments for several decades and plants-based products play a critical role in the treatment of diabetes mellitus (DM) globally. This study was conducted to acquaintancethe effectiveness of gum Arabic (GA)on experimental rats suffered from diabetes mellitus. Thirty six mature male albino rats "Sprague Dawley" strain weighing $(160 \pm 10 \mathrm{~g})$, were used and divided into two main groups, one was kept as a negative control group $(n=6)$ (G1), while the other was injected infraperitoneally with alloxan monohydrate by a single alose of alloxan (150mg/kg/B.W.) in 24 hrs fasting animal. This second main group divided into equal five groups ( $n=6)$;. The five diabetic groups were as the following; Group (2): was left as positive control and fed on basal diet only. Group (3): was fed on basal diet supplemented with diamacron drug $15 \mathrm{mg} / \mathrm{kg}$ diet.Group (4): was fed on basal diet supplemented with $50 \mathrm{~g} \mathrm{GA}(5 \%) / \mathrm{kg}$ diet. Group (5): was fed on basal diet supplemented with $100 \mathrm{~g} \mathrm{GA}(10 \%) / \mathrm{kg}$ diet. Group (6): was fed
\end{abstract}




\section{Ensaf M. Yassin}

on basal diet supplemented with $\mathrm{GA}(10 \%)$ +diamacron drug $15 \mathrm{mg}$ $/ \mathrm{kg}$ diet. Biological evaluation; liver enzymes andlipid profile andlipoprotein fractions were evaluatedin addition to blood glucose and antioxidant enzyme (SOD) estimated. Moreover, histopathological investigation of liver carriedout.The obtained results concluded that supplemented diets withGA, especially at $10 \%$ of diet, improved the level of blood sugar, liver enzymes and lipid profile levels.

\section{Introduction}

Diabetes Mellitus (DM) is a heterogeneous metabolic disorder characterized byaltered carbohydrate, lipid and protein metabolism which causes hyperglycemiresulting from insufficient insulin secretion, insulin action or both (Mutalik et al., 2003 and Joseph and Jini, 2011).DM affects atleast $10 \%$ of the population,worldwide. Complications of DM include hypertension, atherosclerosis, microcirculatory disorders, retinopathy, nephropathy, neuropathy andangiopathy (Edem, 2009). Hyperglycemia can cause oxidative stress, which, in turn, may resultin cellular tissue damage. The harmful influence of diabetes on metabolism of tissuesand organs is well known likewise; uncontrolled hyperglycemia can lead todisturbances in the structure and function of organs (Gupta et al., 2004).

Many hypoglycemic agents, such as the iguanids and sulfonylureas, are usedalone or together with insulin to treat this disease, however these medications cancause serious side 


\section{Egyptian J. of Nutrition Vol. XXXIII No. 3 (2018)}

effects, motivating a search for safer, more efficacious agents tocontrol diabetes (Huang, 2005).

Studies showed that numerous extract obtained from plants are effective inreducingglycemia, causing fewer side effects and with lower cost than the usualantidiabetic agents (Sohn et al., 2010). The majority of the plants that are used in popular medicinefor treatment of DM have been shown to possess biologically active chemicalconstituent such as alkaloids, flavonoids, phenolic substances, and other constituents, that can be used as new hypoglycemic agents (Negri, 2005).

Gum Arabic (GA)is a branched-chain, complex polysaccharide, either neutral orslightly acidic, found as mixed calcium, magnesium and potassium salt of apolysaccharidic acid (Ahmed, 2007).In MiddleEastern countries GA is widely used in the treatment of patients with chronic kidneydisease and endstage renal disease (Al-Majed et al., 2002).

Alloxan has been widely used to produce experimental diabetes mellitussyndrome. It causes necrosis of pancreatic-cells and induces free radicals whichplay a relevant role in the etiology and pathogenesis of both experimental and humandiabetes mellitus (Sotoet al., 2004). Moreover, widespread lipoid deposits throughout the exocrine tissue and loss ofcells result from alloxan injection (Soto et al., 2004).Diabeties are predominantly vulnerable to oxidative stress resultingin the suppression of insulin gene transcription glucose stimulated insulin secretionand even producing apoptosis (Kaneto et al., 2001).There fore,the present 
Ensaf M. Yassin

study was carried out to assess the effects of gum Arabic on the pathological changes reduction of Alloxan induced diabetic rats .

\section{Material and Method}

\section{Materials:}

Thirty six male white albino rats of an average body weight $160 \pm 10 \mathrm{~g}$ of (Sprague Dawley Strain) were used. They were obtained from the laboratory animal house of Faculty of Science, Tanta University.

Alloxan, Casein, vitamins, minerals and cellulose were purchased from EL-Gomhoryia Company, Cairo, Egypt. Gum Arabic"Acacia Senegal" was purchased fromElphraana Company for Chemicals and Drugs, Gharbia Governorate, Egypt.

\section{Experimental design:}

Rats were divided into two main groups as follow: Group (1) was fed on basal diet only and kept as a negative control group ( $n=6$ ). Group (2): Diabetes mellitus was induced in rats using diabetogenic substance alloxan monohydrate, by a single intraperitoneal injection of freshly prepared, in normal saline solution, alloxan $(150 \mathrm{mg} / \mathrm{kg} / \mathrm{B} . W$.) in $24 \mathrm{hrs}$ fasting animal. This dose of alloxan was previously tested and proven to increase blood glucose level above $200 \mathrm{mg} / \mathrm{dl}$ in rats which were considered as diabetic. After that, the rats were divided into equal four groups (6 rats each) as following: Group (2): was left as positive control and fed on basal diet only. Group (3): was fed on basal diet supplemented with diamacrondrug $15 \mathrm{mg} / \mathrm{kg}$ diet. 


\section{Egyptian J. of Nutrition Vol. XXXIII No. 3 (2018)}

Group (4): was fed on basal diet supplemented with $50 \mathrm{~g} \mathrm{GA} \mathrm{(5 \% )}$ $\mathrm{kg}$ diet. Group (5): was fed on basal diet supplemented with 100 g GA (10\%)/ kg diet. Group (6): was fed on basal diet supplemented with GA (10\%) anddiamacron drug $15 \mathrm{mg} / \mathrm{kg}$ diet.GA added on the expense of corn starch. Composition of mineral mixture was according to (Campbell, 1963), the vitamin mixture according to (Hegsted et al., 1941).

Biochemical analysis of serum:

At the end of the experiment, the rats were fasted overnight before sacrificed under ether anesthesia, and the blood samples were collected from each rat, and centrifuged to obtain the serum. Serum was carefully separated and transferred into dry clean eppendorf tubes and kept frozen at- $20^{\circ} \mathrm{C}$ for analysis as described by (Schermer, 1967).Analysis was done at Medical College Laboratory, Zgazig University.

\section{Biochemical analysis}

Different tested parameters in serum were determined using specific methods as follows:Blood glucose according to the method of Tietz (1976) and Yound (1975). Glutamicoxaloacetic transaminase (GOT), glutamic pyruvic transaminase (GPT) were determined in the serum according to the method described by Reitman and Frankel (1957).Total cholesterol, triglycerides and HDLwere determined according to the method described by Allain et al., (1974), Trinder and Ann (1969), Lopes -Virella et al., (1977), respectively.Serum VLDL-C and LDL were calculated according to Friedwald et al., (1972). 


\section{Ensaf M. Yassin}

\section{Statistical analysis}

Data were expressed as mean \pm standard deviation. Values were statisticallanalyzed by one-way analysis of variance (ANOVA test) using SPSS 10.1 software package. Differences were considered significant at $P$ values $(0.05)$.

\section{Results and Discussion}

\section{Biological evaluation:}

The results (Table 1) show that feed intake (FI), body weight gain (BWG g) and feed efficiency ratio (FER) for positive control group $(\mathrm{C}+)$ were significant decreased, as compared to normal rats (negative control group $\mathrm{C}$-). Meanwhile treatment with GA $10 \%$ showed the highest levels of $F I, B W G$ and FER, as compared to all treated groups. The changes in biology measurements might be attributed to the satiety stimulation effect by high fiber intake (Ye et al., 2015), which is associated with beneficial effects on fatmetabolism or lowering caloric density of food (Ali et al.,2009).More detailed explanation was offered byMarciani et al.,(2000) who showed thatgum Arabicdissolves in water, forming a gel-like fluid with a viscous texture. This has the ability to slow the absorption and digestion of carbohydrates by the viscosity effect of dietary. fibers. GA improves bowel movements (Min et al., 2012).GA modifies the body weight and decreased body mass index among healthy adult females (Babiker et al., 2012), reduced weight in rats (Ushida et al., 2011), and reduced visceral adipose tissues in female mice (Ahmed et al.,2015). 
Egyptian J. of Nutrition Vol. XXXIII No. 3 (2018)

\section{Biochemical parameters}

\section{Serum sugar (Glucose):}

Results for glucose recorded significant increase of control (+ve) $(190.34 \pm 8.64 \mathrm{mg} / \mathrm{dl})$, compared to control (-ve) group $(119.33 \pm 5.51 \mathrm{mg} / \mathrm{dl})$ respectively. It denote that all treated groups were significant decrease for glucose, compared to control (+ve) group. The best result found in Arabic gum $10 \%$ with value of $140.33 \pm 13.05 \mathrm{mg} /$ dlas shown in table (2). Dietary fiber plays an important role in controlling postprandial glycemic and insulin response in diabetic patients. There is an extensive literature on the influence of fiber on gastric emptying and its inverse relationship with the regulation of postprandial blood glucose responding in response to various fiber rich nutraceuticals(Kang et al.,2014).Gum Arabic is a non-digestible polysaccharide that has been shown to retard glucose absorption. It has a low glycaemic index and reduces plasma glucose concentrations in healthy individuals (Phillips et al.,2008). Additionally, Omaima, Nasir et al., (2016) showed that GA supplementation caused an overall improvement in biochemical factors related to T2DM and its complications. These observations have potential implications for the prevention and management of T2DM and its complications. Additionally, Rasha, et al., (2017) found that the GA group showed significant reduction in fasting plasma glucose (FPG) and HbA1c $(P<0.05)$ within the GA group. Moreover, gum Arabic is a dietary supplement for improving nutrition of type 2 diabetic patients; it has demonstrated a good effect on improving their poor glycemic control. It has also shown improvement in the levels of the lipids and the BMI. 
Ensaf M. Yassin

Mixtures of different types of gum (not including GA) have been shown to inhibit glucose movement in vitro, and lower postprandial blood glucose and plasma insulin in human subjects when incorporated in a drink containing $50 \mathrm{~g}$ glucose. Infusion of meals containing starch showed that a decrease in the digestion rate of starch in the upper small intestine accounted for part of the effect of viscosity on glycemic response, whereas the main effect of gum was apparently to slow gastric emptying (Armed et al., 2015).

\section{Liver enzymes:}

It is clear from table results (3) that there were significant increases for SGPT and SGOT enzymes in the serum of positive control group ( $56.00 \pm 6.25$ and $63.33 \pm 2.08 \mathrm{U} / \mathrm{L}$., respectively), as compared to negative control group $(26.67 \mathrm{~d} \pm 8.14$ and $33.00 \mathrm{~d}$ $\pm 5.00 \mathrm{U} / \mathrm{L}$., respectively. Results denote that all treated groups had significant decrease in serum levels of SGPT and SGOT activities when compared with positive control group. Treated group with gum Arabic $10 \%$ and the group which treated with drug showed the highest decrease of SGPT and SGOT enzyme levels in serum, values were close to negative control group as shown in table (3). The activities of (ALT, AST and ALP) used as biochemical markers for evaluation of early hepatic injury (AbdelAzim et al., 2017). This was also observed in alloxaninduced diabetic animals in this study; blood levels of AST and ALT were elevated in the first 2 weeks after treatment, but only ALT remained significantly elevated at 6,14 and 26 weeks after diabetes induction (Lucchesi et al., 2015). 
A previous study (Lucchesi, 2013) showed that T1DM changed the oxidative balance in the liver of $A L X$-induced diabetic rats over the long-term, which was characterized by a significant increase in reactive oxygen species (ROS) in liver tissue and markedly reduced defense antioxidants. These results suggest that changes in blood liver enzymes (AST and ALT) and the morphological and ultrastructural lesions found in the livers of animals in this study are closely correlated to DM-induced chronic stress in liver cells. However, the molecular pathways by which chronic stress induces histopathological lesions in the liver in patients with T1DM are not clear because the mechanisms of hyperinsulinemia and hepatic and peripheral resistance to insulin are not usually the predominant mechanisms.

Regnell and Lernmark (2011) suggested a role of three mechanisms, separately or in combination, in the pathogenesis of nonalcoholic fatty livers disease (NAFLD) in patients with T1DM: (1) atypical rates or malfunction of lipoproteins would create alterations in triglyceride secretion by liver cells and lead to an accumulation of fat in the liver; (2) activation of transcription factors of hepatic metabolism by hyperglycemia, such as sterol regulatory element-binding proteins (SREBPS) and the carbohydrate response element-binding protein (ChREBP), would promote hepatic lipogenesis; and (3) excess liver glucose transported by the glucose transporter 2 factor (GLUT2) would lead to intrahepatic fat synthesis.

\section{Lipid profile:}

From tables (4\&5): It could be observed that the mean value of total cholesterol, triglycerides, VLDL and LDL of (+ve) 


\section{Ensaf M. Yassin}

control group were higher than (-ve) control group. On the other hand, HDL level was significantly decreased in the serum of rats treated with alloxan (+ve), when compared with (-ve) control group. In all groups treated with $G A$ and drug there were significant decreases in the serum levels of total cholesterol, triglycerides, VLDL and LDL but significant increase in serum level of HDL. The best results in level of total cholesterol and LDL was found in treated group with GA + Drugwhile the group treated with drug followed by GA (5\%) showed the highest increase in the serum level of HDL. As for triglycerides and VLDL the best result recorded by the drug group followed by GA $(10 \%)$.

Several quantitative and qualitative changes in lipoproteins are observed in T1DM patients, (Verges,2009). On the other handRasha, et al.,(2017) found that GA treatment significantly decreased the total cholesterol by $8.3 \%$, triglycerides by $10.9 \%$, LDL $19.2 \%$, and significantly increased HDL level by $19.9 \%$ among $G A$ treated group. The mechanism by which GA intake reduces the plasma cholesterol level may be related to the hypocholesterolemic effect of dietary fibers, which can be explained by many mechanisms, including viscosity effect of dietary fibers (Marciani et al., 2000), increase fecal bile acids, alteration of lipid metabolism (Moundras et al., 1997) and increase number of lipoprotein receptors in the liver (Fernandez et al., 1995).Although this study demonstrated that the consumption of $30 \mathrm{~g}$ of $\mathrm{GA}$ improves nutrition of type 2 diabetic patients by improving FPG, $\mathrm{HbA} 1 \mathrm{c}$, and lipid profiles. 
Egyptian J. of Nutrition Vol. XXXIII No. 3 (2018)

\section{Antioxidant enzymes}

Data in table (6) showed that serum levels of SOD had significant increase in all treated groups, as compared to positive control group except group of rats which were treated with $5 \& 10 \%$ gum Arabic.Treated group with gum Arabic and drug (G5) recorded the best result for SOD level $(0.308 \pm 0.065 \mathrm{U} / \mathrm{L})$ as compared to positive control group $(0.087 \pm 0.0185 \mathrm{U} /)$, as shown intable (6).

Several studies have also shown a potentially protective effect of gum Arabic against gentamicin nephrotoxicity in rats (AlMajed et al., 2002 and Ali et al., 2003), possibly in part through inhibition of the production of oxygen free radicals that cause lipid peroxidation.

There is however evidence that contradicts the theory that gum Arabic has significant antioxidant properties. Ali et al., (2003) demonstrated in a rat model that administration of varying concentrations of gum Arabic in the drinking water did not change significantly levels of free radical scavengers (Ali et al., 2004).

\section{Histopathology examination results}

Microscopically, liver of rat from negative control group revealed the normal histological structure of hepatic lobule (Photo 1). On the other hand, liver of rat from positive control group (G2, basal diet) showedcytoplasmic vacuolization of hepatocytes, Kupfer cells activation (Photo2) and marked fibroplasia in the portal triad (Photo 3). However, liver of rat from drug group (G3, diamacron diet) revealed small vacuoles in the cytoplasm of hepatocytes (Photos4\&5). Meanwhile, liver of rat from GA 
Ensaf M. Yassin

$(5 \%) G 4$, showed small vacuoles in the cytoplasm of some hepatocytes and slight activation of Kupffer cells (Photo 6). Liver of rat from GA (10\%)revealed small vacuoles in the cytoplasm of some hepatocytes and slight activation of Kupffer cells with slight dilatation of hepatic sinusoids (Photos 7\&8). Moreover, liver of ratfrom $\mathrm{GA}(10 \%)+\operatorname{drug} 15 \mathrm{mg} / \mathrm{kg} \operatorname{diet}(\mathrm{G} 6)$ revealed cytoplasmic vacuolization of hepatocytes and slight activation of Kupffer cells (Photo 9).

Lucchesi et al., (2015) reported that rats with T1DM induced by intravenous alloxan (ALX) presented biochemical changes in blood and morphological and ultrastructural lesions in the liver that largely resembled chronic liver disease in humans. Liver changes ranged from the fatty degeneration of liver cells to steatohepatitis and periportal fibrosis. Typically, the observed lesions in the livers of diabetic animals in this study reached all structures of the organ, including both portal areas and sinusoids, and hepatocytes, nuclei, and intracytoplasmic organelles, including a progressive enlargement of sinusoids, micro- and macrovesicular fatty degeneration, steatohepatitis and periportal fibrosis. Further, ultrastructural changes in hepatocytes, particularly the mitochondria, the rough endoplasmic reticulum (rER) and cell nuclei, were also observed. However, whether the observed histopathological changes in the livers of ALX-induced diabetic rats were due to the toxic action of the drug. ALX and streptozotocin (SZ) exert a toxic effect on pancreatic beta cells, which causes T1DM, but this effect extends to the kidneys and livers of animals of several species (Abd-Allah et al., 2002 and Al-Majed et al.,2003). 


\section{Egyptian J. of Nutrition Vol. XXXIII No. 3 (2018)}

Also it was emphasized that insulin plays an important role in the genesis of steatosis in rodent hepatocytes because it modulates the flow of free fatty acids (FFAs) that is transported by protein pathways mediated by 2 and 5 FATPs (fatty acid transport proteins). The actions of 2 and 5 FATP are dose-dependent and bimodal, and they are mediated by insulin receptor substrate-2 (IRS-2) under low concentrations of insulin and insulin receptor substrate-1 (IRS-1) during states of hyperinsulinemia. These observations indicate that an ideal balance in circulating insulin levels is required for the regulation of fat metabolism in the liver (Regnell and Lernmark, 2011). Therefore, deviations from this equilibrium, such as the lack of insulin production (T1DM) or an excess of insulin in the bloodstream because elevated peripheral resistance to insulin action (T2DM) or the inadequate administration of exogenous insulin, lead to fat accumulation in the liver (Kirby et al., 2010). 


\section{Ensaf M. Yassin}

Table (1): Effect of gum Arabic and drug on feedintake (F1), body weight gain(BWG)and feed efficiency ratio (FER) of diabetic rats (Mean \pm SD)

\begin{tabular}{|c|c|c|c|}
\hline$\underbrace{\text { Parameters }}$ & FI g/day & BWG (g) & FER \\
\hline Groups & Meant SD & Meant SD & Meant SD \\
\hline $\begin{array}{l}\text { G1 } \\
\text { Control (-) }\end{array}$ & $19.63^{a} \pm 0.56$ & $11.17^{a} \pm 0.29$ & $0.020^{a} \pm 0.004$ \\
\hline $\begin{array}{l}\text { G2 } \\
\text { Control (+) }\end{array}$ & $14.07^{d} \pm 0.13$ & $-21.01^{d} \pm 0.28$ & $-0.053^{d} \pm 0.003$ \\
\hline $\begin{array}{l}\text { G3 } \\
\text { Drug }\end{array}$ & $15.77^{c} \pm 0.40$ & $-18.74^{c} \pm 0.64$ & $-0.042^{c} \pm 0.002$ \\
\hline $\begin{array}{l}\text { G4 } \\
\text { Arabic gum } 5 \%\end{array}$ & $13.31^{d} \pm 0.53$ & $-24.15^{e} \pm 0.23$ & $-0.065^{e} \pm 0.001$ \\
\hline $\begin{array}{l}\text { G5 } \\
\text { Arabic gum } 10 \%\end{array}$ & $16.76^{b} \pm 0.47$ & $-16.03^{\mathrm{b}} \pm 0.17$ & $-0.034^{b} \pm 0.009$ \\
\hline $\begin{array}{l}\text { G6 } \\
\text { Arabic gum + Drug }\end{array}$ & $12.39^{\mathrm{e}} \pm 0.53$ & $-26.07^{f} \pm 0.22$ & $\quad-0.075^{f} \pm 0.004$ \\
\hline
\end{tabular}

- Values denote arithmetic mean \pm Standard deviation of the mean.

- Means with different letters (a, b, c, d, etc.) in the same column differ significantly at $p \leq 0.05$ using Duncan test and vice versa. 


\section{Egyptian J. of Nutrition Vol. XXXIII No. 3 (2018)}

Table(2): Effect of gum Arabic and drug on blood sugar of diabetic rats (Mean $\pm S D$ )

\begin{tabular}{|c|c|}
\hline $\begin{array}{ll}\text { Parameters } \\
\end{array}$ & Glucose $\mathrm{mg} / \mathrm{dl}$ \\
\hline Groups & Meant SD \\
\hline $\begin{array}{l}\text { G1 } \\
\text { Control (-) }\end{array}$ & $119.33^{d} \pm 5.51$ \\
\hline $\begin{array}{l}\text { G2 } \\
\text { Control (+) }\end{array}$ & $190.34^{a} \pm 8.64$ \\
\hline $\begin{array}{l}\text { G3 } \\
\text { Drug }\end{array}$ & $166.67^{b} \pm 13.80$ \\
\hline $\begin{array}{l}\text { G4 } \\
\text { Arabic gum } 5 \%\end{array}$ & $168.65^{b} \pm 2.31$ \\
\hline $\begin{array}{l}\text { G5 } \\
\text { Arabic gum } 10 \%\end{array}$ & $140.33^{c} \pm 13.05$ \\
\hline $\begin{array}{l}\text { G6 } \\
\text { Arabic gum + Drug }\end{array}$ & $160.32^{\mathrm{B}} \pm 10.21$ \\
\hline
\end{tabular}

- Values denote arithmetic means \pm Standard deviation of the mean.

- Means with different letters $(a, b, c, d$, etc.) in the same column differ significantly at $p \leq 0.05$ using Duncan testand vice versa. 


\section{Ensaf M. Yassin}

Table(3): Effect of gum Arabic and drug on liver enzymes of diabetic rats (Mean \pm SD)

\begin{tabular}{|c|c|c|}
\hline \multirow{2}{*}{$\begin{array}{ll}\text { Groups } & \text { Parameters } \\
\end{array}$} & GOT U/L & GPT $U / L$ \\
\hline & Mean \pm SD & Mean \pm SD \\
\hline $\begin{array}{l}\text { G1 } \\
\text { Control (-) }\end{array}$ & $33.00^{d} \pm 5.00$ & $26.67^{d} \pm 8.14$ \\
\hline $\mathrm{G}_{2}$ & $63.33^{\mathrm{a}} \pm 2.08$ & $56.00^{a} \pm 6.25$ \\
\hline G3 & $40.67^{\mathrm{cd}} \pm 3.21$ & $33.00^{\mathrm{ad}} \pm 2.00$ \\
\hline $\mathrm{G} 4$ & $49.33^{\circ} \pm 7.09$ & $43.00^{\mathrm{bec}} \pm 4.36$ \\
\hline G5 & $35.00^{c d} \pm 4.58$ & $25.00^{d} \pm 7.55$ \\
\hline G6 & $43.00^{\mathrm{bc}} \pm 3.61$ & $44.66^{b} \pm 4.04$ \\
\hline \multicolumn{3}{|c|}{$\begin{array}{l}\text { Values denote arithmetic means } \pm \text { Standard deviation of } \\
\text { the mean. }\end{array}$} \\
\hline \multicolumn{3}{|c|}{$\begin{array}{l}\text { Means with different letters }(a, b, c, d \text {, etc.) in the same } \\
\text { column differ significantly at } p \leq 0.05 \text { using Duncan test and } \\
\text { vice versa. }\end{array}$} \\
\hline
\end{tabular}


Egyptian J. of Nutrition Vol. XXXIII No. 3 (2018)

Table(4): Effect of gum Arabic and drug on T.Ch and T.G of diabetic rats (Mean $\pm S D$ )

\begin{tabular}{|c|c|c|}
\hline \multirow{2}{*}{ Groups Parameters } & T.Ch $\mathrm{mg} / \mathrm{dl}$ & T.G mg/d \\
\hline & Mean \pm SD & Meant SD \\
\hline $\begin{array}{l}\text { G1 } \\
\text { Control (-) }\end{array}$ & $85.00^{\circ} \pm 4.36$ & $71.00^{c} \pm 1.00$ \\
\hline $\begin{array}{l}\text { G2 } \\
\text { Control (+) }\end{array}$ & $146.33^{a} \pm 6.51$ & $116.00^{a} \pm 6.25$ \\
\hline $\begin{array}{l}\text { G3 } \\
\text { Drug }\end{array}$ & $113.00^{b} \pm 7.58$ & $75.00^{\mathrm{bc}} \pm 6.08$ \\
\hline $\begin{array}{l}\text { G4 } \\
\text { Arabic gum } 5 \%\end{array}$ & $127.33^{\circ} \pm 9.81$ & $86.33^{b} \pm 6.66$ \\
\hline $\begin{array}{l}\text { G5 } \\
\text { Arabic gum } 10 \%\end{array}$ & $117.33^{b} \pm 0.58$ & $75.66^{b c} \pm 5.51$ \\
\hline $\begin{array}{l}\text { G6 } \\
\text { Arabic gum + Drugg }\end{array}$ & $108.33^{b} \pm 14.15$ & $85.67^{\natural} \pm 9.02$ \\
\hline
\end{tabular}

- Values denote arithmetic means \pm Standard deviation of the mean.

- Means with different letters $(a, b, c, d$, etc.) in the same column differ significantly at $p \leq 0.05$ using Duncan test and vice versa. 


\section{Ensaf M. Yassin}

Table(5): Effect of gum Arabic and drug on VLDL, LDL and HDL of diabetic rats (Mean $\pm S D$ )

\begin{tabular}{|c|c|c|c|}
\hline Parameters & VLDL mg/df & LDL $\mathrm{mg} / \mathrm{dl}$ & $\mathrm{HDL} \times \mathrm{C} \mathrm{mg} / \mathrm{dl}$ \\
\hline Groups & Meant SD & Meant SD & Meant SD \\
\hline $\begin{array}{l}\text { G1 } \\
\text { Control }(-)\end{array}$ & $14.20^{d} \pm 1.50$ & $22.80^{\circ} \pm 2.00$ & $48.00^{2} \pm 5.00$ \\
\hline $\begin{array}{l}\text { G2 } \\
\text { Control (+) }\end{array}$ & $23.20^{a} \pm 0.90$ & $83.46^{a} \pm 5.50$ & $39.67^{c} \pm 2.08$ \\
\hline $\begin{array}{l}\text { G3 } \\
\text { Drug }\end{array}$ & $15.00^{\circ} \pm 1.00$ & $47.67^{c} \pm 2.25$ & $50.33^{\mathrm{a}} \pm 3.06$ \\
\hline $\begin{array}{l}\text { G4 } \\
\text { Arabic gum } 5 \%\end{array}$ & $17.27^{b} \pm 1.22$ & $62.73^{\mathrm{b}} \pm 3.20$ & $47.33^{a b} \pm 2.31$ \\
\hline $\begin{array}{l}65 \\
\text { Arabic gum } 10 \%\end{array}$ & $15.13^{\mathrm{cd}} \pm 0.75$ & $60.20^{b} \pm 1.44$ & $42.00^{b c} \pm 1.00$ \\
\hline $\begin{array}{l}\text { G6 } \\
\text { Arabic gum + Drug }\end{array}$ & $17.13^{b c} \pm 1.25$ & $45.87^{c} \pm 1.90$ & $45.33^{a b} \pm 3.21$ \\
\hline
\end{tabular}

Values denote arithmetic means \pm Standard deviation of the mean.

- Means with different letters $(a, b, c, d$, etc.) in the same column differ significantly at $p \leq 0.05$ using Duncan test and vice versa. 
Egyptian J. of Nutrition Vol. XXXIII No. 3 (2018)

Table (6): Effect of gum Arabic and drug on SOD of alloxan diabetic rats (Mean \pm SD)

\begin{tabular}{|c|c|}
\hline \multirow{2}{*}{$\begin{array}{ll}\text { Groups } & \text { Parameters } \\
\end{array}$} & SOD UIL \\
\hline & Meant SD \\
\hline $\begin{array}{l}\text { G1 } \\
\text { Control }(-)\end{array}$ & $0.200^{\mathrm{abc}} \pm 0.003$ \\
\hline $\begin{array}{l}\text { G2 } \\
\text { Control }(+)\end{array}$ & $0.087^{\circ} \pm 0.0185$ \\
\hline $\begin{array}{l}\text { G3 } \\
\text { Drug }\end{array}$ & $0.232^{a k} \pm 0.077$ \\
\hline $\begin{array}{l}\text { G4 } \\
\text { Arabic gum } 5 \%\end{array}$ & $0.184^{\mathrm{abc}} \pm 0.094$ \\
\hline $\begin{array}{l}\text { G5 } \\
\text { Arabic gum } 10 \%\end{array}$ & $0.152^{b c} \pm 0.095$ \\
\hline $\begin{array}{l}\text { G6 } \\
\text { Arabic gum + Drug }\end{array}$ & $0.308^{a} \pm 0.065$ \\
\hline
\end{tabular}

- Values denote arithmetic means \pm Standard deviation of the mean.

- Means with different letters ( $a, b, c$, d, etc.) in the same column differ significantly at $p \leq 0.05$ using Duncan test and vice versa. 


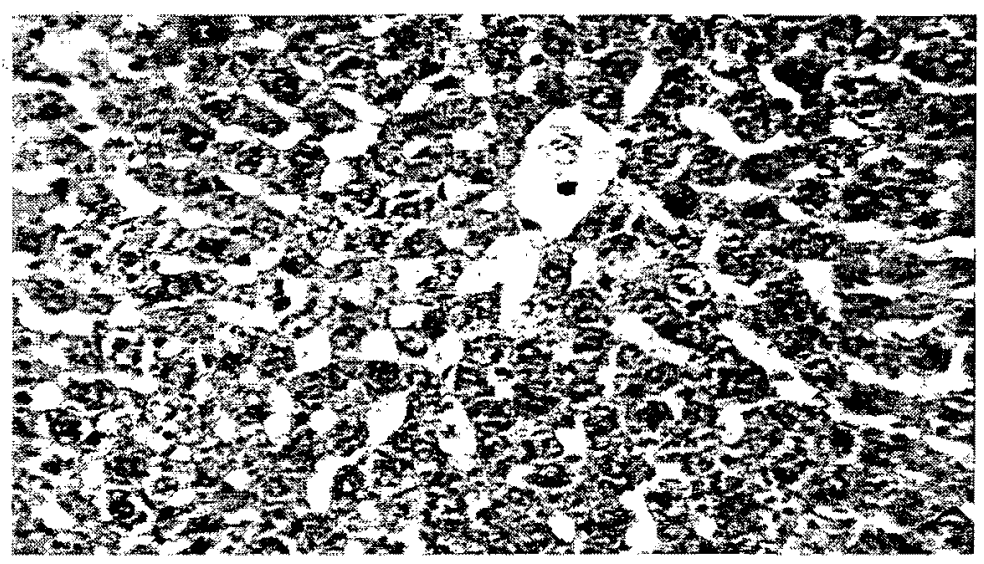

Photo (1): Liver of rat from negative control group ( $\mathrm{G} 1$, basal diet) showing the normal histological structure of hepatic lobule ( $H \& E X 400)$

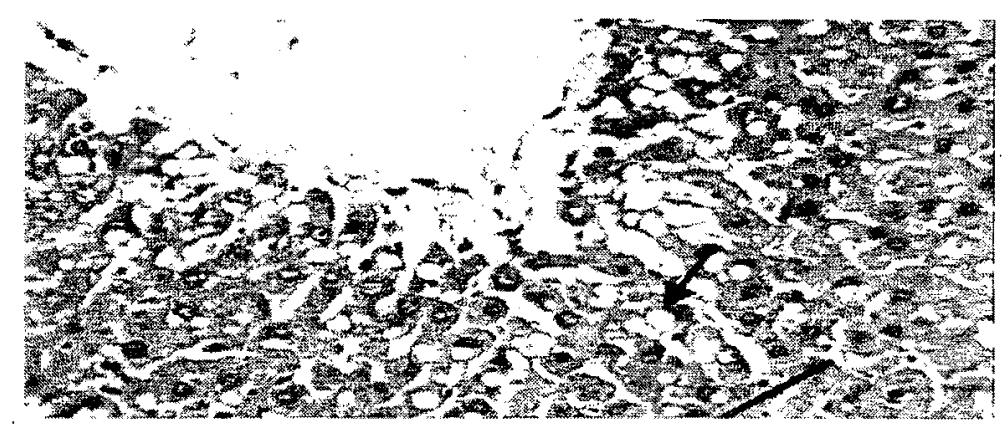

Photo(2): Liver of rat from positivecontrolgroup (G2, basal diet) showing cytoplasmic vacuolization of hepatocytes and Kupffer cells activation ( $\mathrm{H} \& \mathrm{EX}$ 400) 
Egyptian J. of Nutrition Vol. XXXIII No. 3 (2018)

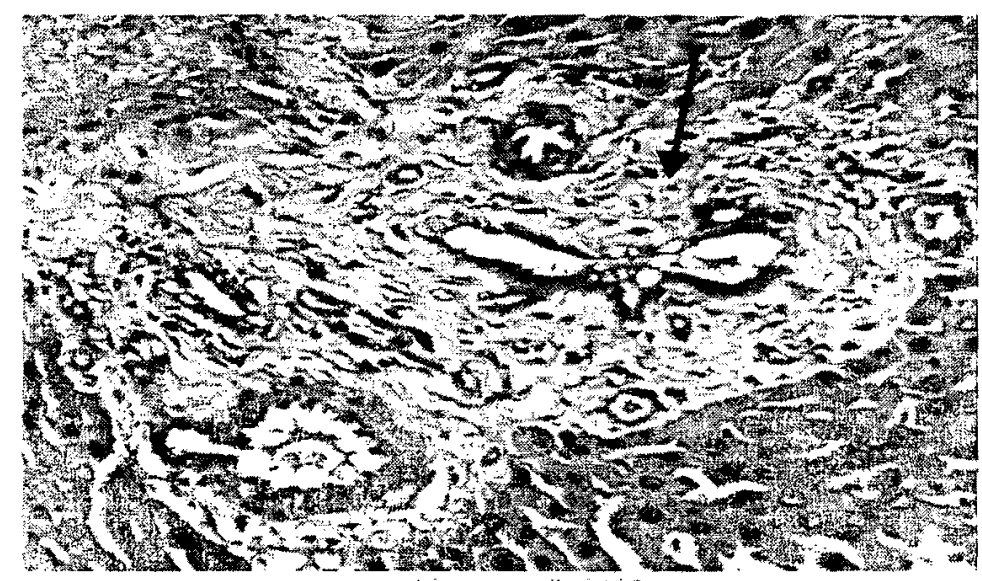

Photo(3): Liver of rat from positivecontrolgroup $(G 2$, basal diet) showing marked fibroplasia in the portal triad (H\&EX 400)

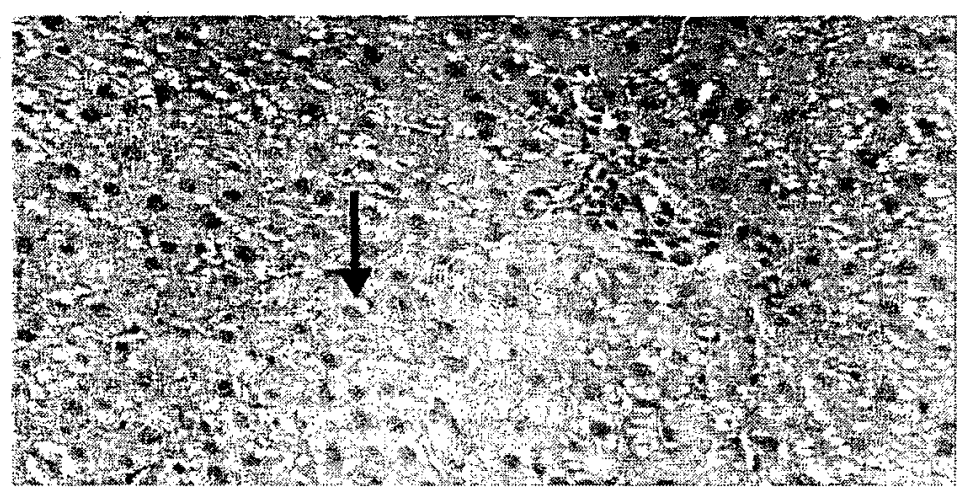

Photo(4): Liver of rat from drug group (G3, diamacron diet) showing small vacuoles in the cytoplasm of hepatocytes $(H \& E X 400)$ 


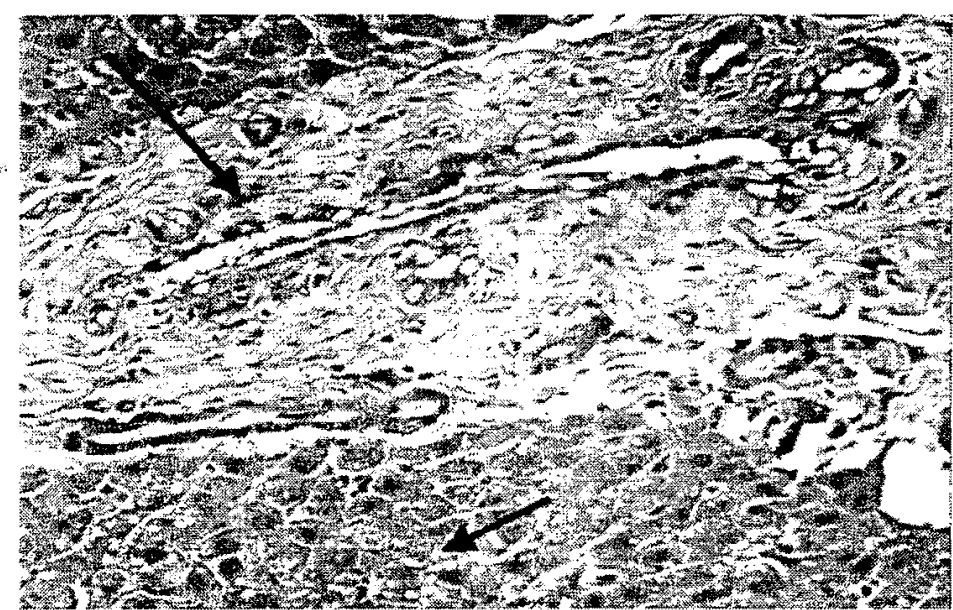

Photo(5): Liver of rat from drug group(G3, diamacron diet) showing small vacuoles in the cytoplasm of hepatocytes andfibroplasia in the portal triad ( $H \& E X 400)$

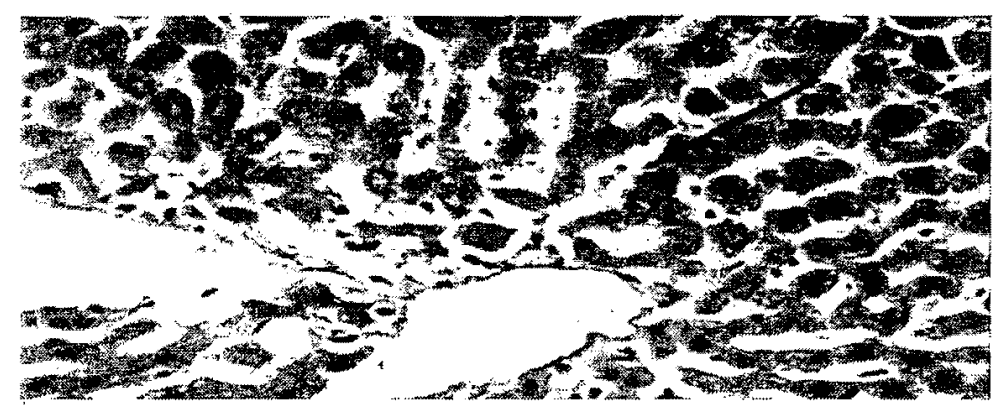

Photo(6): Liver of rat from GA (5\%) (G4) showing small vacuoles in the cytoplasm of some hepatocytes and slight activation of Kupffer cells ( $H$ \& E X 400) 


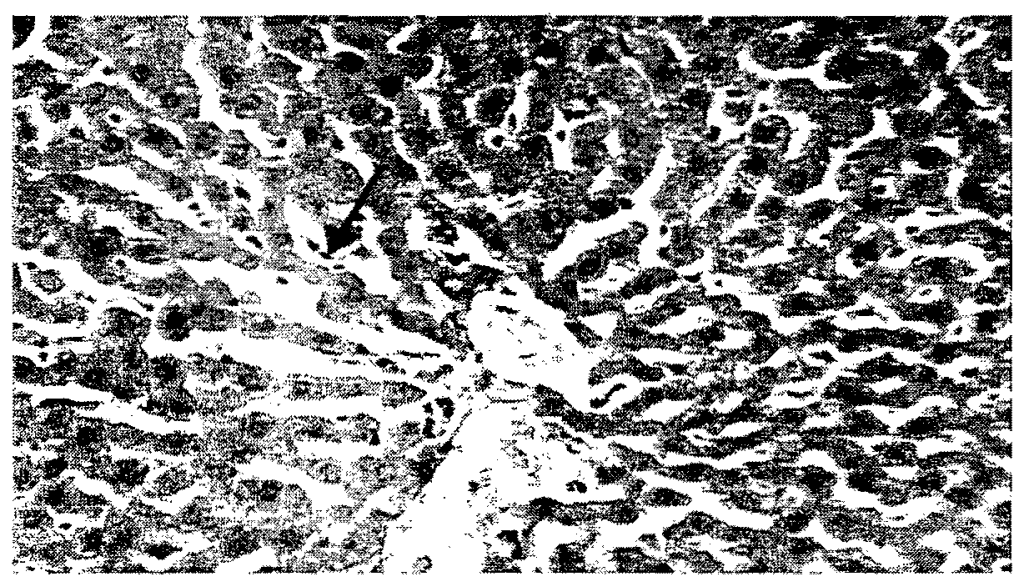

Photo(7): Liver of rat from GA (10\%) (G5) showing slight activation of Kupffer cells (H\& EX 400)

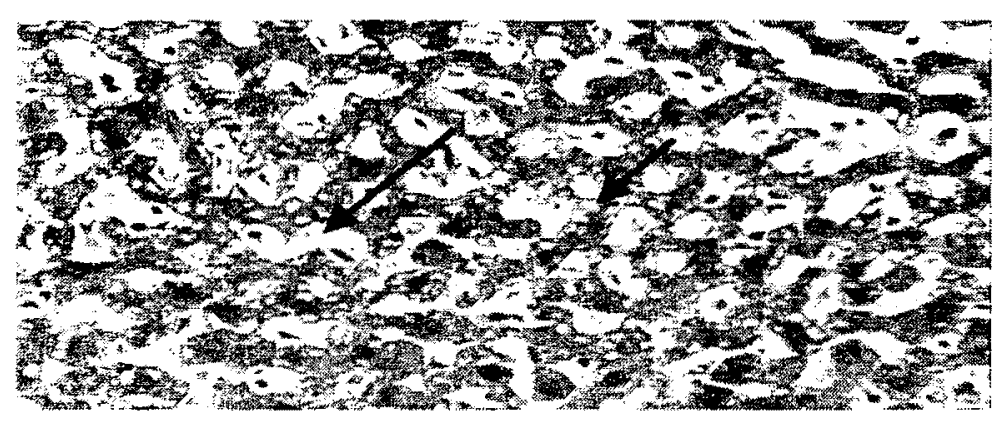

Photo(8): Liver of rat from GA (10\%) (G5) showing small vacuoles in the cytoplasm of some hepatocytes and slight dilatation of hepatic sinusoids ( $H$ \& EX 400) 


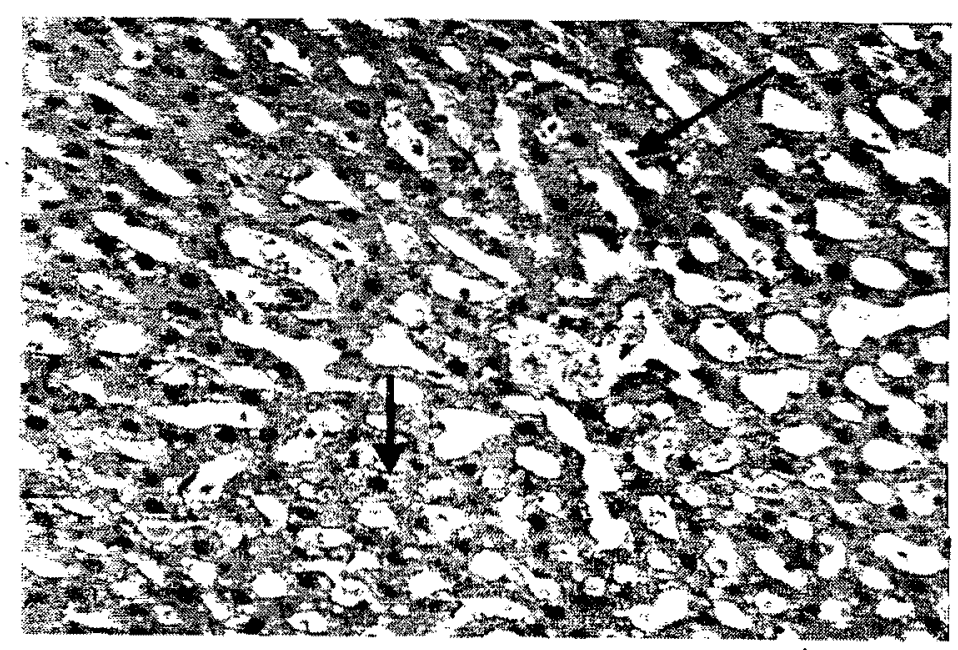

Photo(9): Liver of rat from GA(10\%)+drug $(15 \mathrm{mg} / \mathrm{kg}$ diet) group(G6) showing cytoplasmic vacuolization of hepatocytes and slight activation of Kupffer cells ( $H \& E \times 400$ ). 
Egyptian J. of Nutrition Vol. XXXIII No. 3 (2018)

\section{References}

Abd-Allah, A.R.;Al-Majed, A.A.;Mostafa, A.M.; Al-Shabanah, O.A.;Din, A.G. andNagi,M.N.(2002):

Protective effect of gum Arabic against cardiotoxicity induced by doxorubicin in mice: a possible mechanism of protection. J. Biochem. Mol. Toxicol., 16: 254-259.

Abdel Azim, S.A.; Abdelrahem, M.T.; Said,M. M. and khattab, A. (2017):

Protective effect of moringaperegrina leaves extract on acetaminophen -induced liver toxicity in albino rats. Afr. J. Tradit. Complement Altern. Med., 14(2): 206-216.

Ahmed, A.A.; Musa, H.H. ;Fedail, J.S.;Sifaldin, A.Z. and Musa T.H.(2015):

Gum Arabic decreased visceral adipose tissue associated with downregulation of $11 \beta$-hydroxysteroid dehydrogenase type $I$ in liver and muscle of mice. Bioact Carbohydrates Diet Fiber, 6(1):31-6.

Ahmed, A.S. (2007):

TheurapeuticEffects of Leaves Obtained from some Trees in Egypt on the Experimented Rats, M.SC. Thesis, Faculty of Home Economics, MenoufiaUniversity.

Ali, B.H.;Alqarawi,A.A. and Ahmed, I.H. (2004):

Does treatment with gum Arabic affect experimental chronic renal failure in rats? Fundam.Clin. Pharmacol., 18(3): 327-9.

Ali, B.H.;Ziada, A. and Blunden, G.(2009):

Biological effects of gum Arabic: A review of some recent research. Food Chem. Toxicol., 47(1):1-8. 
Ensaf M. Yassin

Ali, B.H.;Al-Qarawi, A.A.; Haroun, E.M.and Mousa HM(2003):

The effect of treatment with gum Arabic on gentamicin nephrotoxicity in rats: A preliminary study. Ren.Fail., 25(1):15-20.

Allain, C.C.; Poon, L.S. and Chan, C.S. (1974):

Enzymatic determination of serum total cholesterol.Clin. Chem., 20: 470-475.

Al-Majed, A.A.; Abd-Allah, A.R.; Al-Rikabi, A.C.; Al

Shabanah, O.A. and Mostafa, A. M. (2003):

Effect of oral administration of gum Arabic on cisplatininduced nephrotoxicity in rats. J.Biochem Mol.Toxicol., 17: 146-153.

Al-Majed, A.A.et al., (2002):

Protective effects of oral Arabic gum administration on gentamicin-induced nephrotoxicity in rats. Pharmacol. Res. 46 (5): $445-451$.

Babiker, R.;Merghani, T.H.;Elmusharaf, K.;Badi, R.M.; Lang F. andSaeed, A.M. (2012):

Effects of gum Arabic ingestion on body mass index and body fat percentage in healthy adult females:Two-arm randomized, placebo controlled, double-blind trial. Nutr J., 11(1):1-7.

Campbell, J.A. (1963):

Methodology of Protein Evaluation, PAG. Nutr. Document R. 101 Add. 37, June, Meeting, New York.

Edem, D.O. (2009):

Hypoglycemic effects of ethanol extracts of alligator pear seed in rats. European Journal of Scientific Research, 33:669-678. 
Egyptian J. of Nutrition Vol. XXXIII No. 3 (2018)

Fernandez, M.L.; Ruiz, L.R.;Conde, A.K.; Sun, D.M.; Erickson, S.K. andMcnamara, D.J.(1995):

Psyllium reduces plasma LDL in Guinea-pigs by alterting hepatic cholesterol homeostasis. J. Lipid Res., 36 (5): $1128-38$

Friedwald, W.T.; Leve, R.I. and Fredrickson, D.S. (1972):

Estimation of the concentration of low-density lipoprotein separated by three different methods. Clin. Chem., 18: 499-502.

Gupta, S.; Kataria, M.; Gupta, P.K.;Murganandan, S. and Yashroy, R.C. (2004):

Protective role of extracts of neem seeds in diabetes caused by streptozotocin in rats. Journal of Ethnopharmacology, 90:185-189.

Hegsted, D.M.; Mills, R.C.; Elvehjen, C.A. and Hart, E.B. (1941):

Choline in chicks. J. Biol. Chem., 138:459.

Huang, P.H. (2005):

Enhanced coronary calcification determined by electron beam $C T$ is strongly related to endothelial dysfunction in patients with suspected coronary artery disease. Chest, 128(2): 810-815.

Joseph, B. and Jini, D. (2011):

An insight in hypoglycemica effect of traditional Indian herbs used in the treatment of diabetes. Research Journal of Medicinal plant, 5:352-376. 
Kaneto, H.; Xu, G.; Song, K.H.; Suzuma, K.; Bonner-Weir, S.; Sharma, A. and Weir, G.C. (2001):

Activation of the hexosamine pathway leads to deterioration of pancreatic beta cell function through the induction of oxidative stress. J. Biol. Chem., 276: 3109931104.

Kang, Y.; Mei-Yun, K.; Wen-Hui, L.;Shu-Qin, Z. B. and XiuCai,F. (2014):

The impact of soluble dietary fibre on gastric emptying,postprandial blood glucose and insulin in patients with type 2 diabetes. Asia Pac. J. Clin.Nutr.,23(2):210-218.

Kirby,S. M.; Shroyer, N. and Kohli, R. (2010):

Hepatic steatosisin type 2 and type 1 diabetes mellitus is mediated by insulinsignaling via fatty acid transport proteins. Journal of Pediatric Gastroenterology and Nutrition, 51(2): E33-E34.

Lopes-Virella, M.F.; Stone, S.; Ellis, S. and Collwell, J. A. (1977):

Cholesterol determination in high-density lipoprotein separated by three different methods. Clin. Chem., 23 (5): 882.

Lucchesi, A. N.;Cassettari, L. L. and Spadella, C.T(2015):

Alloxan-Induced Diabetes Causes Morphological and Ultrastructural Changes in Rat Liver that Resemble the Natural History of Chronic Fatty Liver Disease in Humans. Journal of Diabetes Research, Volume 2015 (2015), Article ID 494578,11 pages.

Lucchesi, A.N.; Freitas, N.T.; Cassettari,L.L.;Marques, S.F.G. and Spadella, C. T. (2013):

Diabetes mellitus triggers oxidative stress in the liver of alloxan-treated rats: a mechanism for diabetic chronic liver disease.ActaCirurgicaBrasileira, 28(7): 502508. 
Egyptian J. of Nutrition Vol. XXXIII No. 3 (2018)

Marciani, L.;Gowland, P.; Spiller, R.C.;Manoj, P.; Moore, R.J. and Young, P.et al.,(2000):

Gastric response to increased meal viscosity assessed by echo-planar magnetic resonance imaging in humans.J.Nutr., 130(1):122-7.

Min, Y.W.; Park, S.U.; Jang, Y.S.; Kim, Y.H.; Rhee, P.L. andKo, S.H.et al., (2012):

Effect of composite yogurt enriched with acacia fiber and Bifidobacteriumlactis. World J. Gastroenterol., 18(33):4563-9.

Moundras, C; Behr, S.R.;Rémésy, C. andDemigné, C. (1997): Fecal losses of sterols and bile acids induced by feeding rat's guar gum are due to greater pool size and liver bile acid secretion. J. Nutr., 127(6):1068-76.

Mutalik, S.;Sulochana, B.;Chetana, M.; Udupa, N. and Uma Devi, U.P.(2003):

Preliminary studies on acute and subacute toxicity of an antidiabetic herbal preparation, Dianex Indian Journal of Experimental Biology, 4:316- 320.

Negri G, (2005):

Diabetes melito : plantas e princ-pios ativosnaturaishipoglice-miantes.Brazilian Journalof

Pharmaceutical Sciences, 41:121-141.

OmaimaNasir, SawsanBabiker and Abdel-Moneim M. Salim(2016):

Protective effect of gum Arabic supplementation for type 2

diabetes mellitus and its complications.Int. J.of Multidisciplinary and Current research, 4: 2321-3124. 
Ensaf M. Yassin

Phillips, G.O.; Ogasawara, T. and Ushida, K.(2008):

The regulatory and scientific approach to defining gum Arabic(Acacia senegal and Acacia seyal) as a dietary fiber. Food Hydrocolloids, 22(1): 24-35.

Rasha, Babiker; Elmusharaf, K.; Keogh, M. B.; Banaga, A. S. I. and Amal M. Saeed (2017):

Metabolic effects of gum Arabic (Acacia senegal) in patients with type 2 diabetes mellitus (T2DM): Randomized, placebo controlled double blind trial. Functional Foods in Health and Disease, 7(3): 219-231.

Reitman, S. and Frankel, S. (1957):

A colorimetric method for the determination of serum glutamic oxaloacetic and glutamic pyruvic transaminases. Am. J. Clin. Path. , 28: 56.

Regnell, S. E. and Lernmark, A. (2011):

Hepatic steatosis in type 1diabetes. Review of Diabetic Studies, 84 (4): 454- 467.

Schermer, S. (1967):

The Blood Morphology of Laboratory Animal. Longmans, Printed in Great Britain, Green and Co.LTd, P. 350.

Sohn, E.s.; Kim, J.; Kim, C.S.; Kim, Y.S.; Jang, D.S. and Kim, J.S. (2010):

Extract of the aerial par ts of Aster koraiensis reduced development of diabetic nephropathy via antiapoptosis of podocytes in streptozotocin induced diabetic rats. Biochem.Biophys.Res.Commun., 391: 733-738.

Soto, C.; Mena, R.; Luna, J.; Cerbon, M.; Larrieta, E.; Vital, P.;Uria, E.; Sanchez, M.; Recoba, R.; Barron, H.; Favri, L. and Lara, A. (2004):

Silymarin induces recovery of pancreatic function after alloxan damage in rats. Life Sci., 75 (18): 2167-2180. 
Egyptian J. of Nutrition Vol. XXXIII No. 3 (2018)

Tietz, N. W. (1976):

Fundamental of Clinical Chemistry. Philadelphia, W. B. Sauders, P243.

Trinder, P. and Ann, S. (1969):

Enzymatic colorimetric test with lipid clearing factor to determine triglycerides. Clin.Biochem., $6: 24-27$.

Ushida, K.;Hatanaka, H.; Inoue, R.;Tsukahara, T. and Phillips, G.O.(2011):

Effect of long term ingestion of gum Arabic on the adipose tissues of female mice. Food Hydrocoll. Elsevier Ltd;25(5):1344-9. 22.

Verges, B. (2009):

Lipid disorders in type 1 diabetes. Diabetes and Metabolism, 35(5):353-360.

Ye, Z;; Arumugam, V.;Haugabrooks, E.; Williamson, P. andHendrich, S.(2015):

Soluble dietary fiber (Fibersol-2) decreased hunger and increased satiety hormones in humans when ingested with a meal. Nutr. Res., 35(5):393-400.

Yound, D.S. (1975):

Determination of GOT. Clin. Chem., 21:1. 
Ensaf M. Yassin

التأثيرات الفذائية والبيوكيميائية للصبخ العزبي فلي التغيرات المرضية للحد من السكر المحدث بالالموكسان في الفئران

إنصاف مختار يس

قسم التفذية وعلوم الأطعة كلية الإقتصاد المنزلني جامعة الأزهر

الملخص العربي

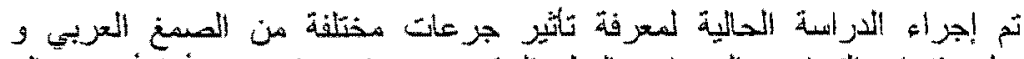

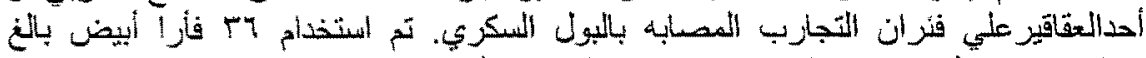

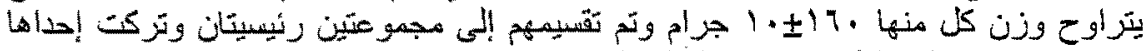

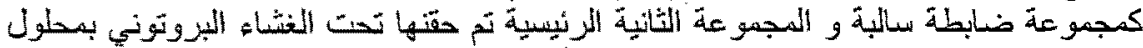

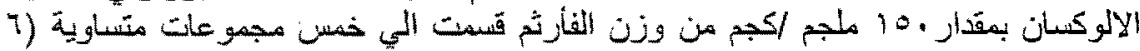

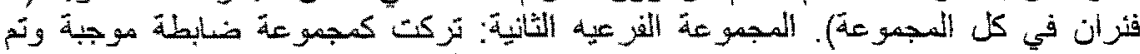

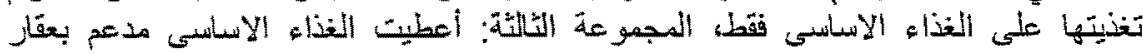

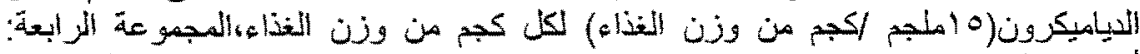

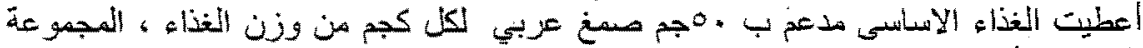

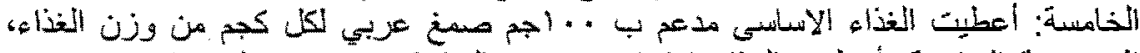

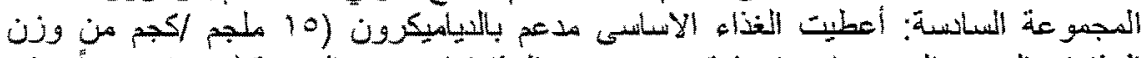

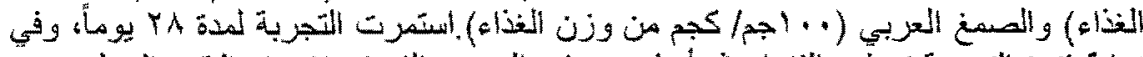

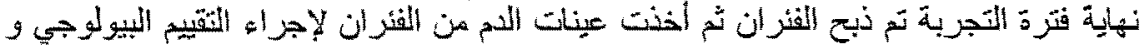

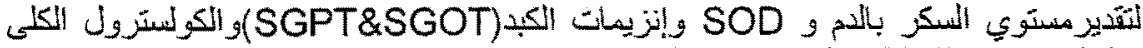
والجلنسريدات الثلاثية والبروتينيات الدهنية في الثم (HDL-C, LDL-C, VLDL-C)

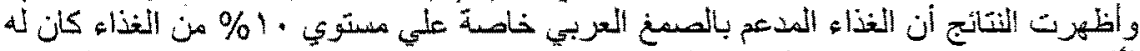

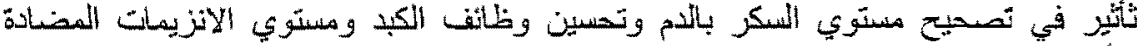
للأكسدة ودهون الَّم. 